\title{
ITGAX Gene
}

National Cancer Institute

\section{Source}

National Cancer Institute. IT GAX Gene. NCI Thesaurus. Code C28529.

This gene is involved in the initiation of immune cell chemotaxis and phagocytosis. 